\title{
Russian Fishing Activities off the Coast of Finnmark-A Legal History ${ }^{1}$
}

\section{Kirsti Strøm Bull*,}

Professor, Faculty of Law, University of Oslo, Oslo, Norway

\begin{abstract}
The rich fishery resources off the coast of Finnmark have historically attracted fishermen from other parts of Norway and from neighbouring countries. This article discusses the legal history of Russian fishing activities off the coast of Finnmark and covers the historical period from the 1700s until the termination of this fishery in the early 1900s. The article shows that Russian fishermen, like the Sámi from Finland - and unlike fishermen from other nations, were authorized to establish shacks and landing places. Both the agreements and legal disputes surrounding the fishery, which lasted until World War I, are discussed in the article.
\end{abstract}

Keywords: fishery; Russia; legal history; rights to marine resources; Finnmark; The Lapp Codicil

Received: August 2014; Accepted: September 2014; Published: March 2015

\section{Introduction-protecting fishery resources for the benefit of Finnmark's own population}

From far back in time, the rich fisheries off the coast of Finnmark have attracted fishermen from beyond the county's own borders. Some of these fishermen, known in Norwegian as nordfarere ("northern seafarers"), came from further south along the Norwegian coast, specifically from the counties of Nordland and Trøndelag. Others came from further east, from Finland and Russia. In more recent times, fishermen started to arrive from even further afield, notably from England. When the English trawlers ventured into Varangerfjord in 1911, they triggered a dispute between Norway and England concerning the delimitation of the Norwegian fisheries zone that continued until 1951, when the matter was decided by the International Court of Justice in The Hague.

During the 18th and 19th centuries, Norwegian officials were mainly concerned with protecting fisheries resources for the benefit of Finnmark's own population. Royal ordinances were issued that were intended to prevent the nordfarere, whose presence in Finnmark was merely of a seasonal nature, from depriving the year-round

${ }^{\star}$ Correspondence to: Kirsti Strøm Bull, Professor, Faculty of Law, University of Oslo, NO-0316 Oslo, Norway. Email: k.s.bull@jus.uio.no 


\section{K. S. Bull}

local population of Finnmark of access to the fisheries. A royal ordinance dating from 1778 provided that the nordfarere could only fish from "the outer isles off Finnmark [Ud-Øerne $i$ Finmarken]". In other words, the nordfarere were only permitted to fish from places uninhabited by the local population. ${ }^{2}$

As a general rule, fishermen from other countries were not permitted to fish within Norway's territorial limits at all. Moreover, while the extent of the territorial limit was only one sea mile, ${ }^{3}$ as a practical matter it was impossible to operate a fishing vessel off the Finnmark coast, regardless of the territorial limit, without access to facilities on shore. It was essential for fishermen to have a place to shelter on shore, to put the fish out on racks to dry, and to repair their equipment. With two exceptions, however, foreign fishermen were banned from spending time ashore. These exceptions applied to fishermen from Russia and to Sámi from Sweden-Finland.

\section{The Lapp Codicil of 1751}

In 1751 , a treaty between the King of Denmark-Norway ${ }^{4}$ and the King of Sweden established the border between Norway and Sweden (and the territory that later became Finland). ${ }^{5}$

The border cut straight across the territory used by the Sámi for reindeer husbandry. As a result, the treaty had an appendix, known as the Lapp Codicil, which addressed the position of the Sámi. According to Section 10 of the Codicil, the Sámi were permitted "as was accorded to them by ancient custom to migrate, in autumn and spring, with their reindeer across the border into the other Kingdom [efter gammel Scedvane vare dennem tilladt, Høst og Vaar, at flytte med deres RehnHiorder over Grendsen ind $i$ det andet Rige]." As part of these arrangements, Sámi from Sweden-Finland enjoyed hunting and fishing rights-including coastal fishing rights - on the Norwegian side of the border.

Those Sámi who migrated between Norway and Sweden-Finland, as permitted under the Lapp Codicil, enjoyed the same rights to fish off the coast of Finnmark as the county's permanent inhabitants. Accordingly, the restrictions that applied to the nordfarere did not apply to Sámi from the Finnish side of the border, who came with their reindeer to the coast of Finnmark during the summer. ${ }^{6}$ Indeed, for many of these Sámi access to the coastal fisheries was the primary motivation for their seasonal migration. Finnmark's coastal fisheries were extremely important for the Utsjoki and Inari Sámi, for whom reindeer husbandry was merely a secondary reason for migrating. ${ }^{7}$ The coastal fishing rights accorded by the Lapp Codicil to Sámi inhabiting the border territory were purely for the benefit of the Sámi. They did not apply to other inhabitants of Sweden-Finland. ${ }^{8}$

\section{Russian fisheries and the royal rescript of 1747}

Like the nordfarere and the Sámi, Russian fishermen had also fished along the coast of Finnmark for centuries. A royal rescript dated 10 February 1747 gave Russian fishermen the right to maintain quarters on shore while fishing in the area. Unlike the 
nordfarere, however, the Russians were not confined to areas uninhabited by the local population. However, the Russians were only permitted to fish outside Norway's territorial limit, which extended for one sea mile from the coast (see note 3). The rescript also mandated that Russian fishermen pay a fee for each fishing vessel.

In a note to the authorities (Rentekammeret) in Copenhagen, the governor of Finnmark, Rasmus Kjeldsen, wrote that when he arrived in Vardø in 1743, there were 14 active Russian fishing vessels, the crews of which had either built their own houses or had rented accommodation. In the following years, Russian fishing vessels continued to arrive in Finnmark. The Russians not only fished in the best fishing grounds, but also collected driftwood - wood that the local population needed for construction and fuel. The governor wrote that residents of Vardø and Kiberg in particular had lodged strong complaints about the Russians' behaviour. In spite of all the complaints regarding the Russians, however, the governor allowed them to anchor their vessels subject to payment of a fee, so long as they restricted their fishing activities to areas more than one sea mile offshore. The governor's approach was certainly influenced by the fact that the local population were in the habit of entering Russian territory for the purposes of gathering firewood and lichen. Clearly a ban on Russian fishing activities would have carried the risk of inciting a tit-for-tat ban on the gathering of much-needed firewood and lichen. This was the background cited in the royal rescript of $1747 .{ }^{9}$

A note authored in 1775 by the governor of Finnmark, Amtmann Fjeldsted, provides evidence of the presence of large numbers of Russian fishermen in Finnmark. According to Fjeldsted, the Russians had erected 13 dwellings on Sørøya and had overwintered on the island. There were 36 Russian vessels at Sørøya, 15 at Hammerfest, and as many as 63 at Måsøy. Another 19 Russian vessels were anchored at Kjelvik on the island of Magerøya, a further three at Kjøllefjord, and 29 at Omgang. ${ }^{10}$ Meanwhile at Vardø there were as many as 79 Russian fishing vessels. Each boat had a crew of four or five men, which meant that, in total, approximately 1,000 Russian fishermen were present in Finnmark. Amtmann Fjeldsted further noted that fish caught by the Russians was being transported to Arkhangelsk (Archangel). ${ }^{11}$

The Russians also had a strong presence in Finnmark due to the Pomor trade. ${ }^{12}$ The Pomor Russians bartered for fish by offering other goods in return, usually flour. They bought up fish caught in July and August, which were not attractive for Norwegian buyers. In return, the local fishermen obtained rye flour and oatmeal, generally obtaining sufficient supplies of these necessary provisions to see them through the winter.

\section{Russian fisheries in the 19th century}

During the 19th century a trade monopoly applied in Finnmark, and the wealthy merchants who controlled the monopoly looked with disfavour on the Pomor trade. This trade was discussed during negotiations on a trade treaty between Russia and Denmark-Norway signed in $1782 .{ }^{13}$ The Danes wanted to put an end to the Pomor 


\section{K. S. Bull}

trade in Finnmark, and the Russians issued a decree to the effect that the Russian Tsar forbade his subjects from trading and bartering in Finnmark. Nonetheless, Russian fishermen were allowed, in an emergency, to seek refuge in Finnmark, and while there had the right to trade in necessary goods, repair their equipment, and salt their fish. Otherwise Russian fishermen were banned from trading with the inhabitants of Finnmark. Not only was the Pomor trade banned, but Russian fishing activities off Finnmark were adversely affected.

The ban on Russian trading activities in Finnmark can scarcely have been enforced particularly strictly, since we have evidence of the importance of the Pomor trade during precisely this period. A few years later, in 1787, the trade monopoly was abolished and all restrictions on trade were lifted in Finnmark. The commission that prepared the royal ordinance concerning free trade in Finnmark declared that Russian fishing activities in Finnmark were not damaging to Norwegian interests, especially if Norwegian subjects were to be granted permission to fish along the Russian coast.

Even though the Russian presence was not viewed as damaging, this did not mean that it was not a source of conflict. Russian fishing activities were limited to sea fishing, but the vessels cannot have operated particularly far out to sea, given that complaints against the Russians cited the fact that they put out their lines so close to shore that they prevented other vessels from accessing the most important fishing banks. ${ }^{14}$ In 1817, the authorities in Finnmark obtained the assistance of a naval vessel to ensure that the Russians did not fish within the one-sea-mile limit established under the rescript of $1747 . .^{15}$

In 1830, new statutory rules were adopted concerning fishing off the coast of Finnmark. ${ }^{16}$ The commission responsible for drafting the rules also considered the rules applicable to Russian fishing activities. In the commission's opinion, the Russian coastal fishing activities - which were conducted primarily off Eastern Finnmark - were not damaging provided that these activities were made subject to necessary restrictions. Accordingly, the commission did not wish to abolish the rescript of 1747 concerning the right to fish beyond the one-sea-mile limit. The commission pointed out that it would be impossible for the Russian fishermen to take advantage of these fisheries if they were not allowed to spend time ashore. Rules to this effect were accordingly set forth in section 40 of the 1830 statute, which provided that Russian fishermen should have the right to anchor their vessels in the harbours of Kiberg, Hamningsberg, Båtsfjord, Berlevåg, Gamvik and Stensvik.

An overview of the situation during the period 1831 to 1892 shows that throughout this period the Russian fishermen used Kiberg as their base during the fishing season. In 1891, 106 Russian vessels, crewed by 424 men, were registered as present at Kiberg. This is the highest figure mentioned in the overview. According to the document, the Russian fishermen do not appear to have exercised their right to anchor at the other places permitted under the 1830 statute, apart from at Hamningberg during the first 10 years. ${ }^{17}$ 
In many cases the Russian fishermen failed to adhere to the one-sea-mile limit. Between 1866 and 1870, a total of 51 Russian captains were fined for fishing too close to shore. ${ }^{18}$

Russian fishing activities were also considered by a commission established in 1867. ${ }^{19}$ Given that the Russians had only been present in Kiberg during the previous 20 years, the commission proposed that in future their presence should be restricted to Kiberg, and that they should henceforth be barred from the other fishing harbours to which they had been granted access under the statute of 1830 . In return, the commission suggested that they should be allowed to fish within the one-sea-mile territorial limit. This suggestion was made in the light of the extreme difficulties experienced in ensuring that the Russians adhered to the one-sea-mile limit. In the commission's view, it would be better for them to have a single base, rather than being distributed further afield. The ministry, however, was unable to support the proposal. A trade treaty with Russia dating from 1838 gave certain advantages to Norwegian exporters of herring and saltfish to Russia. These advantages were conditional upon the maintenance of the access given to Russians by the statute of 1830 to the fisheries off the coast of Finnmark. This meant that Norway could not amend the statute of 1830 without entering into negotiations with Russia. The foreign minister for Sweden-Norway ${ }^{20}$ did not consider it appropriate to ask Russia to enter into such negotiations. Accordingly, the rules governing Russian access to the fisheries off Finnmark remained unchanged. ${ }^{21}$

A new law concerning saltwater fishing off Finnmark was passed in $1897 . .^{22}$ The commission that drafted this statute considered once again the question of Russian fishing activities in Finnmark. The commission determined that the access to shore-based facilities enjoyed by Russian fishermen in Finnmark was greatly to the disadvantage of Norwegian fishermen. The commission highlighted the fact that Norwegian fishermen did not enjoy equivalent privileges along the coast near Murmansk. Since the Russian privileges in Finnmark were wholly dependent on Norwegian law, Norway was free to revoke them. On the other hand, there was the issue of the advantages granted to Norwegian exporters of herring and saltfish to Russia by virtue of the trade treaty of 1838 , which as mentioned above were dependent on the continuance of Russian access to fisheries off the coast of Finnmark. When exports of herring and saltfish were taken into account, it became clear that it was important to retain the advantages granted to the Norwegian export trade under the 1838 trade treaty. In the light of these considerations, the commission did not find it advisable to abolish the rules of the 1830 statute concerning Russian fishing activities. ${ }^{23}$ The commission emphasised however that it was important to ensure that the restrictions placed on the Russian fishermen under the 1830 statute were adhered to. Specifically, there were several examples of Russian fishing vessels based in places that were not permitted under the 1830 rules. In recent years, for example, many Russian vessels had maintained a presence in Vardø. On a single day in 1888, the presence of 70 Russian vessels, crewed by 300 men, had been recorded in the harbour at Vardø. In spite of strong warnings from both the Norwegian authorities and the Russian vice consul, the Russians were not willing 


\section{K. S. Bull}

to leave. The Russians claimed that they were not in breach of the statutory provisions so long as they stayed on board their vessels with their fishing equipment and gutted the fish on board.

The following year saw the arrival of even more Russian vessels at Vardø, leading to vociferous complaints from the Vardø Fishermen's Association. The illegal fishing came to an end however the following year with the passing of the Act of 8 April 1890 concerning the registration and marking of fishing vessels (merkeloven). This act required the captains of vessels fishing out of harbours in Finnmark to report to the fisheries authority for registration. This made it easier for the authorities to crack down on any Russian vessel present in a harbour where it was not permitted.

The Russians tried to evade these new rules. On arrival in Finnmark, they would enter into pro forma sales of their vessels to Norwegian businessmen. They would then repurchase their vessels at the end of the fishing season. This meant that the Norwegian businessman was technically the captain of the vessel during the actual fishing season, so the Russians could operate as share fishermen (i.e., participants in a cooperative fishing arrangement known in Norwegian as lottfiske), which was permitted under a law passed on 17 June 1869.

\section{The end of Russian fisheries in Finmark}

By the beginning of the 20th century, the advantages enjoyed by Norwegian herring and saltfish exporters under the trade treaty of 1838 had lost their significance. There were also far fewer Russian boats engaged in coastal fishing activities in Finnmark. In 1910, there were only six Russian vessels with a total of 20 men. ${ }^{24}$ Accordingly, in 1911 the Ministry of Trade proposed the abolition of the provision in the 1830 act permitting Russian fishing activities off Finnmark, in effect banning the Russians from fishing off Finnmark. The proposal encountered significant opposition from members of parliament representing Finnmark. They saw the proposal as a hostile act towards Russia, and feared that such a ban would affect the important Pomor trade. In their opinion, the motivation for the proposal lay in foreign policy considerations. This was denied by both the foreign minister and the trade minister. $^{25}$

The legislative proposal was passed by the Storting ${ }^{26}$ and obtained royal approval on 17 March 1911. It did not come into force, however, until 1 January 1913. Whether the ban on Russian fisheries would have affected the Pomor trade remains an open question. This is because 18 months later other more dramatic events put a stop to the trade: namely, the First World War and thereafter the Russian Revolution.

\section{Bibliography and sources}

Bull, Kirsti Strøm: Kystfisket i Finnmark —en rettshistorie, Oslo 2011.

Document No. 79 (1868-69)-Betænkning fra den ved kongelig Resolution af 21de Januar 1867 anordnede Kommission til Revision af Lovgivningen om Torskefiskeriern i Finmarken. 
Eriksen, Knut Einar and Niemi, Einar: Den finske fare-Sikkerhetsproblemer og minoritetspolitikk i nord 860-1940, Oslo-Bergen-Tromsø 1981.

Finmarkens Amts Femaarsberetninger

Forhandlingene i Odelstinget (1911)

Forhandlingene i Lagtinget (1911)

Friis, J. A.: En Sommer i Finmarken, Russisk Lapland og Nordkarelen, Christiania 1871.

Haffner, Wilhelm: Innstillinger og betenkninger fra kongelige og parlamentariske kommisjoner, departementale komiteer m.m. 1814-1924, Oslo 1925.

Indstilling fra den ved Kongelig Resolution af 12te December 1891 nedsatte Kommission til Revision af Lovgivningen om Fiskerierne i Finmarken, avgitt 1893 (The Finnmark Fisheries Commission)

Indst. O. nr. 16 (1911)-Indstilling fra næringskomite nr. 1 om utfærdigelse av en lov om forandring av lov om fiskerierne i Finmarken eller Vest- og Øst-Finmarkens fogderier av 13de september 1830 .

Kristiansen, Tom: “Russerne ødelagge os; de berøve os vor Naring ..." Norge og Russland $i$ nord ca. 1820, Historisk Tidsskrift 1997 nr. 1 pp. 21-49

Niemi, Einar (ed.): Partisanbygda Kiberg, Vadsø 2007.

O. No. 23 (1868-1869) - Om Forandringer i Lov af 7de September 1854 angaaende Reenbete i Finmarken.

Pedersen, Steinar: Lappekodisillen $i$ nord 1751-1859: fra grenseavtale og sikring av samenes rettigheter til grensesperring og samisk ulykke, Tromsø 2006.

Wessel-Berg, Fr. Aug.: Kongelige Rescripter, Resolutioner, og Collgial-Breve for Norge 1660-1813, Christiania 1841-1847.

\section{NOTES}

1. This article is based on my book Kystfisket i Finnmark - en rettshistorie [The coastal fisheries of Finnmark - a legal history] (2011), one topic of which is Russian fishing activities off the coast of Finnmark.

2. Royal Ordinance of 20 August 1778, section 32 .

3. See the Royal Decree of 25 February 1812 (Cancelli-Promemoria) on the extent of the Danish territorial sea. Prior to 1875 , one sea mile was calculated as equivalent to 7,435 metres. In 1875 , however, the distance was fixed as $1 / 15$ of a degree of equatorial arc, which is equal to 7,421 metres.

4. Between 1380 and 1814, Norway was in a union with Denmark. As a result of the Napoleonic Wars, Denmark was forced to cede Norway to Sweden under the Treaty of Kiel, signed in January 1814. Sweden gained Norway as compensation for the loss of Finland (see note 5 below). Norway's union with Sweden lasted until 1905.

5. In 1751 Finland was part of Sweden. In 1809 Sweden surrendered Finland to Russia and the region became an autonomous Grand Duchy. Finland achieved independence in 1917.

6. Steinar Pedersen, Lappekodisillen $i$ nord 1751-1859: fra grenseavtale og sikring av samenes rettigheter til grensesperring og samisk ulykke 2006, Sámi University College, Kautokeino, 64.

7. Op. cit., 66.

8. Op. cit., 64 .

9. Fr Wessel-Berg, Kongelige Rescripter, Resolutioner, og Collgial-Breve for Norge 1660-1813, vol. 2. 1746-1780 (1842), 20-21. 
10. Omgang is close to Gamvik.

11. Amtmann Fjelsted's notes are reproduced in J. A. Friis, En Sommer i Finmarken, Russisk Lapland og Nordkarelen (1871), 269.

12. The Pomor trade refers to the trade that took place from the 18th century until the early 20th century between Russian merchants from the White Sea region and the population of the coasts and fjords of Finnmark and Troms. The word "Pomor" means "by the ocean" and refers to a Russian seafarer from the region adjacent to the White Sea.

13. At this time Norway was in a union with Denmark, see note 4 above.

14. Report from the Finnmark Fisheries Commission, published in 1893, 52.

15. On the conflict with Russian fishermen that led to assistance being provided by a naval vessel, see Tom Kristiansen, "Russerne ødelagge os; de berøve os vor Naring..." Norge og Russland i nord ca. 1820, in Historisk Tidsskrift, Norwegian Fournal of Historical Studies no. 1, (1997): 21-49.

16. Act of 13 September 1830 concerning fisheries in Finnmark or in the districts of Western and Eastern Finnmark.

17. Report from the Finnmark Fisheries Commission, published in 1893, 55-57.

18. Of these, 39 agreed to pay the fine, while 12 only paid up following court proceedings. See Finmarkens Amts Femaarsberetninger, 1866-70, 19.

19. See Document 79 No. (1868-69).

20. At this time Norway was in a union with Sweden, see note 5 above.

21. O. No. 23 (1868-69), 4-5.

22. Act no. 5 of 3 August 1897 concerning the saltwater fisheries of Finnmark.

23. Report from the Finnmark Fisheries Commission, published in 1893, 58.

24. Indst. O. nr. 16 (1911), 22.

25. Forhandlingene i Odelstinget (1911), 54-68 and Forhandlingene i Lagtinget (1911), 3-14. For further details on the background of, and debate surrounding, this act, see Knut Einar Eriksen and Einar Niemi, Den finske fare (1981), 99-106.

26. The Norwegian Parliament. 